\title{
Faktor-Faktor Yang Mempengaruhi Minat Mahasiswa Untuk Berinvestasi Di Pasar Modal
}

(Studi Empiris Pada Mahasiswa Akuntansi Di Universitas Swasta Di Kota Bengkulu)

\author{
Heldi Sahputra ${ }^{1,}$ Ahmad Junaidi ${ }^{2}$, Meido Ade Putra ${ }^{3}$ \\ ${ }_{1,2 \& 3}$ Universitas Muhammadiyah Bengkulu \\ $\underline{\text { heldisahputra@umb.ac.id }}{ }^{1}, \underline{\text { rasi-jundi@yahoo.com.sg }}{ }^{2}, \underline{\text { meido.putra@gmail.com }}{ }^{3}$
}

\begin{abstract}
The background in this research is the lack of interest of students to invest in the capital market. The number of students who invest in the Investment Gallery has not reached $10 \%$ of the total number of students at the Private University in Bengkulu City. The problem in this research is to discuss whether the variables of knowledge, motivation, minimal capital, return, risk and benefits affect the interest of students in investing in the capital market. The purpose of this study is to determine whether the variables have effect on knowledge, motivation, minimal capital, return, risk, and benefits of students' interest in investing in the capital market. The research was a type of quantitative research, using the sample of 265 students. The sampling technique was done by using the sample size table developed by Isaac and Michael. The data collection techniques used was a questionnaire. The data was analyzed using classical assumptions, $\mathrm{t}$ - test, f-test, and multiple linear regression. Based on the results of multiple linear regression obtained by the regression equation $\mathrm{Y}=0.682+0.178 \mathrm{X} 1+0.083 \mathrm{X} 2+0.133 \mathrm{X} 3$ $+0.271 \mathrm{X} 4+0.078 \mathrm{X} 5+0.134 \mathrm{X} 6+\mathrm{e}$. The results of the hypothesis test simultaneously showed the variables of knowledge, motivation, minimal capital, return, risk and benefits have a positive and significant effect $(\operatorname{sig} \alpha=0,000)$ on the interest of students investing in the capital market. Partially, knowledge variables ( $\operatorname{sig} \alpha=0,001)$, motivation ( $\operatorname{sig} \alpha=0,049)$, minimal capital ( $\operatorname{sig} \alpha=$ 0.003 ), return ( $\operatorname{sig} \alpha=0,000)$, risk ( $\operatorname{sig} \alpha=0,005)$, and the benefits $(\operatorname{sig} \alpha=0$, 001) have a positive and significant effect on the interests of students investing in the capital market. From the results of the t- test carried out, it can be concluded that the variable of knowledge, motivation, minimal capital, return, risk and benefits partially affect the interest of students to invest in the capital market. Ftest results show variable knowledge, motivation, minimal capital, return, risk and benefits simultaneously affect the interest of students to invest in the capital market.
\end{abstract}

Keywords: Knowledge, Motivation, Minimal Capital, Return, Risk, Benefits, Investment Interest.

\section{PENDAHULUAN}

Perkembangan ekonomi dan teknologi komunikasi yang sangat pesat memberikan begitu banyak kemudahan dalam dunia bisnis. Pasar Modal adalah wadah untuk berinvestasi yang sudah tidak asing lagi di telinga semua kalangan berbagai profesi di Indonesia maupun Mancanegara, salah satunya di kalangan mahasiswa 
terutama jurusan Akuntansi. Investasi merupakan salah satu dari instrumen pembangunan yang dibutuhkan oleh suatu negara dalam rangka meningkatkan kesejahteraan masyarakat, termaksud Indonesia. Salah satu bentuk investasi yang sering digunakan adalah investasi yang di lakukan di pasar modal.

Indonesia sebagai Negara berkembang dikenal memiliki lahan yang cukup subur dan sumber daya alam yang berlimpah, sebagai Negara yang berkependudukan terbesar keempat didunia, Indonesia memiliki peluang cukup besar untuk meningkatkan jumlah investor. Keikut sertaan masyarakat dalam berpartisipasi melakukan investasi dapat dikatakan bahwa masyarakat tersebut ikut ambil bagian untuk mengembangkan perekonomian Indonesia. Karena, investasi mempunyai peran penting dalam pembangunan ekonomi suatu Negara. Dengan adanya investor individu maupun badan usaha dapat menyalurkan kelebihan dana yang dimilikinya untuk di investasikan, dan para pengusaha dapat memperoleh dana tambahan untuk memperluas jaringan usahanya dari para investor dan membuka peluang lapangan kerja untuk masyarakat sekitar (sartika, 2018:1).

Investasi dalam arti luas berarti mengorbankan rupiah sekarang untuk rupiah pada masa depan. Pengorbanan terjadi saat sekarang ini dan memiliki kepastian. Hal baru akan diperoleh kemudian dan besarannya tidak pasti (Poppy Nurmayanti, 2010:1). Saat ini pemerintah serius mengupayakan pengembangan industri pasar modal di Indonesia. Hal ini dibuktikan dengan program yang di selenggarakan oleh PT Bursa Efek Indonesia (BEI) melalui kampanye "Yuk Nabung Saham" guna mengajak masyarakat untuk mulai berinvestasi di pasar modal, dimulai dengan meningkatkan kesadaran masyarakat akan pentingnya berinvestasi saham yang selanjutnya dapat menaikkan jumlah investor lokal juga menyejahterakan perekonomian masyarakat Indonesia.

Pasar modal memberikan alternatif bagi para investor untuk berinvestasi baik jangka pendek maupun jangka panjang, yang pada dasarnya akan menyebabkan para investor tertarik untuk menginvestasikan dananya. Saham merupakan salah satu komoditas keuangan yang diperdagangkan dipasar modal yang paling popular dan banyak diminati. Sebelum mengenal akan adanya investasi banyak orang yang menyisihkan uangnya dalam bentuk tabungan, akan tetapi dengan perkembangan zaman dan kecangihan teknologi orang-orang sekarang lebih memilih untuk menyisihkan uangnya dengan cara membeli saham, obligasi atau logam mulia yang menurut mereka akan memberikan keuntungan yang menjajikan untuk masa depan. Beberapa hal diduga dapat mempengaruhi minat seseorang untuk berinvestasi dipasar modal yaitu, pemahaman seseorang akan cara berinvestasi dipasar modal, modal untuk berinvestasi tidaklah besar dengan modal yang minimal dapat melakukan investasi, dan motivasi untuk menunjukan eksistensi diri mereka, (Aminatun Nisa, 2017:22).

Penelitian terdahulu yang dilakukan oleh Arlin Ferlina dan Riswan Kuswardhana (2017) di Universitas Telkom ditemukan hasil Informasi produk dan kepuasan investor berpengaruh secara parsial terhadap minat mahasiswa berinvestasi saham, 
sedangkan kepuasan investor secara parsial tidak berpengaruh dan Informasi produk, risiko investasi dan kepuasan investor secara simultan berpengaruh terhadap minat mahasiswa berinvestasi saham dengan besarnya pengaruh $70,6 \%$. Penelitian terdahulu yang dilakukan oleh Nensy Herawati dan Noviansyah (2018) di STIE Widya Gama Lumajang menenmukan hasil bahwa lima variabel manfaat investasi, modal minimal investasi, motivasi investasi, return investasi, dan edukasi pembelajaran investasi, hanya dua variabel yang dapat mempengaruhi minat mahasiswa untuk berinvestasi di pasar modal yaitu return investasi dan edukasi pembelajaran investasi.

Manajemen Bursa Efek Indonesia (BEI) terus berupaya meningkatkan jumlah investor di pasar modal. Galeri investasi ini merupakan kerjasama tiga pihak antara BEI, UMB dan Phintraco Sekuritas yang bertujuan untuk mengenalkan Pasar Modal sejak dini. Galeri Investasi BEI di UMB ini merupakan galeri investasi yang ke 349 di seluruh Indonesia dan merupakan yang keenam di Provinsi Bengkulu.

Kepala Kantor Perwakilan OJK Provinsi Bengkulu, Yan Syafri, menyampaikan, pendirian GI BEI di UMB juga bertujuan untuk mengenalkan dan mendekatkan investasi di pasar modal kepada mahasiswa, pemerintah daerah, instansi, asosiasi profesi dan masyarakat di Kota Bengkulu. Pendirian GI ini juga didasarkan pada masih rendahnya tingkat literasi dan inklusi tentang produk investasi yang legal di masyarakat yang menyebabkan produk-produk investasi ilegal atau bodong masih kerap beredar dan memakan korban, (Pedomanbengkulu.com).

Menjadi investor sejak mengenyam pendidikan di perguruan tinggi bukanlah hal sulit. Saat ini Bursa Efek Indonesia (BEI) teleh bekerja sama dengan berbagai perguruan tinggi untuk menyediakan fasilitas galeri investasi. Hal ini dilakukan untuk menjaring kalangan mahasiswa untuk menjadi investor di pasar modal. Galeri investasi juga bertujuan meningkatkan literasi mahasiswa terhadap dunia pasar modal. Erna mengatakan, ada berbagai manfaat dan keuntungan jika mahasiswa sudah menjadi investor di pasar modal. Selain bisa memahami seluk beluk bursa saham, nantinya mahasiswa bisa menjadi seorang investor yang andal, karena sudah memiliki pengetahuan dan pengalaman yang ditanamkan sejak kuliah, (kompas.com).

Dengan kemajuan teknologi saat ini masyarakat bisa berinvestasi saham dengan modal hanya Rp 100.000. Cara investasi saham Rp 100.000 ini terbilang mudah. Cukup mendaftar ke perusahaan sekuritas yang saat ini tersebar di beberapa galeri investasi. "Sekarang ini perusahaan sekuritas yang bekerja sama dengan perguruan tinggi, mereka punya galeri investasi. konteksnya lebih ke mahasiswa dan kalangan kampus tetapi juga sekarang ke masyarakat umum juga tetapi tetap perusahaan sekuritas memberikan kemudahan dalam bentuk setoran Rp 100.000. Dengan uang Rp 100.000 kita bisa mendapatkan 1 lot saham yang harganya Rp 1.000/lembar. Investasi yang ditawarkan berupa saham dan reksa dana, (detik.com). 
Universitas Muhammadiyah Bengkulu juga membuka sebuah wadah untuk para mahasiswanya agar lebih mudah lagi untuk berinvestasi yaitu dengan hadirnya Galeri Investasi. Dari data yang diperoleh peneliti yang bersumber dari wawancara dengan Ibu Ade Tiara Yulinda, S.E., M.M, Galeri Investasi Universitas Muhammadiyah Bengkulu pada tanggal 21 Oktober 2019 dari total 789 mahasiswa akuntansi, hanya 33 mahasiswa akuntansi yang sudah membuka akun "yuk nabung saham".

Data yang diperoleh peneliti yang bersumber dari wawancara dengan Bapak Idham Lakoni, S.E., M.Si, direktur Galeri Investasi Universitas Prof. DR. Hazairin, SH pada tanggal 5 November 2019, jumlah mahasiswa akuntansi yang sudah membuka akun di GI UNIHAZ sebanyak 55 orang dari total jumlah mahaiswa akuntansi UNIHAZ yaitu 130 orang. Data yang diperoleh peneliti yang bersumber dari wawancara dengan Bapak Rinto Noviantoro, S.E., M.Si., Ak, CA, direktur Galeri Investasi Universitas Dehasen pada tanggal 6 November 2019, jumlah mahasiswa akuntansi yang sudah membuka akun di GI UNIVED sebanyak 15 orang dari total jumlah mahasiswa akuntansi UNIVED sebanyak 133 orang.

Penelitian ini merupakan replika dari penelitian terdahulu yang dilakukan oleh Nensy (2018) dengan judul faktor-faktor yang mempengaruhi minat mahasiswa untuk berinvestasi di pasar modal. Adapun perbedaan antara penelitian sekarang dengan penelitian terdahulu adalah dengan menambahkan variabel independen yang diteliti yaitu variabel risiko investasi, jumlah sampel yang diteliti dalam penelitian ini sebanyak 265 mahasiswa akuntansi, lebih banyak dibandingkan dengan penelitian terdahulu yaitu sebanyak 100 mahasiswa akuntansi, dan cakupan objek yang diteliti lebih luas, penelitian terdahulu hanya melakukan penelitian pada mahasiswa akuntansi di satu universitas, sedangkan pada penelitian sekarang melakukan penelitian pada mahasiswa akuntansi di universitas swasta yang ada di kota Bengkulu. Berdasarkan latar belakang di atas, maka peneliti tertarik untuk mengambil judul "Faktor-Faktor Yang Mempengaruhi Minat Mahasiswa Untuk Berinvestasi Di Pasar Modal".

\section{TINJAUAN PUSTAKA}

\section{Investasi}

Investasi didefinisikan sebagai saham penukaran uang dengan bentuk bentuk kekayaan lain seperti saham atau harta tidak bergerak yang diharapkan dapat ditahan selama periode waktu tertentu supaya menghasilkan pendapatan. Pada umumnya, investasi dibedakan menjadi dua yaitu investasi pada financial asset dan investasi pada real asset. Investasi financial asset dilakukan di pasar uang berupa sertifikat deposito, Surat Berharga Pasar Uang (SBPU) dan juga di pasar modal. Sedangkan investasi real asset dilakukan dengan membeli aset produktif, pendirian pabrik, pembukaan pertambangan, dan lainnya, Salim, H.S dan Sutrisno, (dalam Malik, 2017:66). Investasi bisa dilakukan secara langsung dengan membeli langsung aktiva keuangan yang dapat diperjual belikan di pasar uang, pasar modal atau pasar turunan. Sedangkan investasi yang tidak langsung dilakukan dengan membeli saham dari perusahaan investasi yang mempunyai 
portfolio aktiva keuangan dari perusahaan yang terdaftar di bursa efek Indonesia, (Malik, 2017:67).

\section{Proses Investasi}

Proses investasi menjelaskan bagaimana seharusnya seorang investor membuat keputusan investasi sekuritas yang bisa dipasarkan, seberapa ekstensif dan kapan sebaiknya dilakukan, (Poppy, 2010:5). Dasar pembuatan keputusan untuk berinvestasi:

a. Return

Investor berinvestasi untuk masa depan, berharap bahwa mereka akan memperoleh return yang besar, namun ketika periode investasinya telah selesai, mereka bisa jadi akan memperoleh return yang besar atau return yang kecil. Dalam investasi terdapat perbedaan return ekspektasi dan return realisasi. Return ekspektasi adalah return yang diharapakan pada masa depan, return realisasi adalah return sesungguhnya yang terjadi.

b. Risiko

Risiko adalah kesempatan untuk memperoleh keuntungan (return) atas investasi yang berbeda dari yang diharapkan. Ada investor yang berani untuk mengambil risiko, adapula yang menolak risiko.

\section{Perusahaan Investasi}

Perusahaan investasi (investment companies) adalah perantara keuangan yang mengumpulkan dana dari investor individu dan menginvestasikan dana tersebut ke dalam beragam sekuritas dan aset lain yang potensial. Kumpulan aset merupakan gagasan dasar di balik perusahaan investasi. Setiap investor mempunyai sebuah klaim terhadap portofolio yang di bentuk, proporsional terhadap dana yang diinvestasikan. Oleh karena itu, perusahaan ini menyediakan sebuah mekanisme bagi investor kecil untuk "masuk dalam tim" untuk mendapatkan manfaat dari investasi dalam skala besar, (Bodie, 2014:97).

\section{Pasar Modal}

Definisi pasar modal menurut Kamus Pasar Uang dan Modal adalah pasar konkret atau abstrak yang mempertemukan pihak yang menawarkan dana yang memerlukan dana jangka panjang, yaitu jangka satu tahun ke atas. Umumnya termasuk pihak penawar adalah perusahaan asuransi, dana pension, bank-bank tabungan, sedangkan yang termasuk peminat adalah pengusahaa, pemerintah, dan masyarakat umum, (Totok Budisantoso, 2014:365).

\section{Produk-Produk di Pasar Modal}

\section{Reksa Dana}

Reksa dana (mutual fund) adalah wadah yang dipergunakan untuk menghimpun dana dari masyarakat pemodal untuk selanjutnya diinvestasikan dalam portofolio efek oleh manajer investasi sesuai dengan Undang-Undang pasar modal No. 8 Tahun 1995. Melalui reksa dana ini nasihat investasi yang baik "jangan menaruh semua telur di dalam satu keranjang" bisa dilaksanakan. Pada prinsipnya investasi pada reksa dana adalah melakukan investasi yang 
membayar pada sejumlah alat investasi yang diperdagangkan di pasar modal dan pasar uang, (Totok, 2014:378).

2. Saham Biasa

Saham biasa adalah suatu surat berharga yang di jual oleh suatu perusahaan yang menjelaskan nilai nominal dimana pemegangnya diberi hak untuk mengikuti RUPS dan RUPSLB, serta berhak untuk menentukan membeli right issue (penjualan saham terbatas) atau tidak, yang selanjutnya di akhir tahun akan memperoleh keuntungan dalam bentuk deviden, (Poppy, 2010:33). Saham dapat didefinisikan sebagai tanda penyertaan atau pemilikan seseorang atau badan dalam suatu perusahaan. Imbalan yang akan diperoleh dengan kepemilikan saham adalah kemampuannya memberikan keuntungan yang tidak terhingga. Tidak terhingga ini bukan berarti keuntungan investasi saham biasa sangat besar, tetapi bergantung pada perkembangan perusahaan penerbitnya, (Totok, 2014: 379).

3. Saham Preferen

Saham preferen adalah gabungan (hybrid) antara obligasi dan saham biasa. Artinya di samping memiliki karakteristik seperti obligasi juga memiliki karakteristik saham biasa. Karakteristik obligasi, misalnya saham preferen memberikan hasil yang tetap seperti bunga obligasi. Biasanya saham preferen memberikan pilihan tertentu atas hak pembagian dividen. Saham preferen memiliki karakteristik saham biasa sebab tidak selamanya saham preferen bisa memberikan hasil seperti yang dikehendaki pemegangnya. Jika suatu ketika emiten mengalami kerugian, maka pemegang saham preferen bisa tidak menerima pembayaran dividen yang sudah ditetapkan sebelumnya, (Totok, 2014:380).

4. Obligasi

Obligasi adalah surat berharga atau sertifikat yang berisi kontrak antara pemberi pinjaman dengan penerima pinjaman. Surat obligasi adalah selembar kertas yang menyatakan bahwa pemilik kertas tersebut memberikan pinjaman kepada perusahaan yang menerbitkan obligasi. Obligasi memberikan penghasilan yang tetap, yaitu berupa bunga yang dibayarkan dengan jumlah yang tetap pada waktu yang telah ditetapkan. Obligasi juga memberikan kemungkinan untuk mendapatkan capital gain, yaitu selisish antara harga penjualan dengan harga pembelian, (Totok, 2014:381).

5. Waran

Waran adalah hak untuk membeli saham biasa pada waktu dan harga yang sudah ditentukan. Biasanya waran dijual bersamaan dengan surat berharga lainnya, misalnya obligasi atau saham. Penerbit waran harus memiliki saham yang nantinya dikonversi oleh pemegang waran. Namun, setelah obligasi atau saham yang disertai waran memasuki pasar baik obligasi, saham maupun waran dapat diperdagangkan secara terpisah, (Totok, 2014:382).

6. Right Issue

Right issue adalah hak bagi pemodal membeli saham baru yang dikeluarkan emiten. Karena merupakan hak, maka investor tidak terikat untuk membelinya. Biasanya harga saham hasil right issue lebih murah dari saham lama. Karena membeli right issue berarti membeli hak untuk membeli saham, kalau pemodal 
menggunakan haknya otomatis pemodal telah melakukan pembelian saham. Dengan demikian, imbalan yang akan didapat oleh pembeli right issue adalah sama dengan membeli saham, yaitu dividen dan capital gain, (Totok, 2014:383).

\section{Stock Options}

Stock options (opsi saham) adalah kontrak sederhana yang memperbolehkan pemiliknya untuk menjual (put options) atau membeli (call options) sebuah stock dengan harga yang sudah ditentukan sebelum stock tersebut kadaluwarsa, (Totok, 2014:383).

a. Call options (opsi beli) adalah suatu hak untuk membeli sebuah aset pada harga kesepakatan dan dalam jangka waktu tertentu yang disepakati sebelum jatuh tempo.

b. Put options (opsi jual) adalah suatu hak untuk menjual sebuah aset pada harga kesepakatan dan dalam jangka waktu tertentu yang disepakati sebelum jatuh tempo.

\section{Minat Investasi}

Minat dalam Kamus Besar Bahasa Indonesia (KBBI) didefiniskan sebagai kecenderungan hati yang tinggi terhadap sesuatu gairah ataupun keinginan. Minat adalah kecenderungan yang menetap dalam subyek untuk merasa senang dan tertarik pada bidang atau hal tertentu dan merasa senang dalam bidang itu, Timothi (dalam Ahmad Ulil, 2019:132). Minat (Interest) berarti kecenderungan dan kegairahan yang tinggi atau keinginan yang besar terhadap sesuatu. Menurut Carl safran dan Sukardi (dalam Ahmad Ulil, 2019:132) mengklasifikasikan minat menjadi empat yaitu:

a. Expressed interest yaitu minat yang diekspresikan melalui suatu objek aktivitas.

b. Manifest interest yaitu minat yang disimpulkan dari keikutsertaan individu pada suatu kegiatan tertentu.

c. Invored interest adalah minat dimana berasal dari daftar aktivitas dan kegiatan yang sama dengan pernyataan

d. Tested Interest merupakan minat dari pengetahuan dan ketrampilan suatu kegiatan.

Menurut Lilis (2011:110) dalam tulisannya menyatakan bahwa minat merupakan fungsi kejiwaan atau sambutan yang sadar untuk tertarik terhadap suatu objek baik berupa benda atau yang lain. Selain itu minat dapat timbul karena ada gaya tarik dari luar dan juga datang dari hati sanubari. Minat yang besar terhadap suatu hal merupakan modal besar untuk mencapai tujuan yang diminati dalam hal ini berinvestasi terutama di sektor pasar modal. Dalam penelitianya dikatakan juga bahwa indikator dari seseorang berminat atau tidak maka dibutuhkan deskripsi yang jelas mengenai keberminatan seseorang, hal ini bisa di lihat dari keaktifan seseorang dalam mencari informasi, mengidentifikasi semua persoalan yang di minati, menganalisis, dan membuat daftar tabel tentang sesuatu yang di minati hingga penetapan bidang yang di minati. 
Menurut Salim (dalam Masri, 2014:5) minat memiliki definisi sebagai kecenderungan hati yang tinggi terhadap sesuatu gairah, keinginan. Perluasan dari definisi minat adalah:

1. Minat dianggap sebagai perantara faktor-faktor mati rasional yang mempunyai dampak pada suatu perilaku.

2. Minat menunjukkan seberapa keras seseorang berani mencoba.

3. Minat menunjukkan seberapa banyak upaya yang direncanakan seseorang.

\section{Motivasi Investasi}

Motivasi adalah suatu perangsang atau pendorong yang terdapat pada diri seseorang untuk meningkatkan semangat dan kegairahan kerja dan kedisipilinan sehingga mereka mau melakukan tindakan-tindakan untuk mencapai tujuan tertentu, (Masri, 2014:6). Menurut Malayu (dalam Masri, 2014:5) teori motivasi yang paling terkenal adalah teori hierarki kebutuhan Abraham Maslow. Maslow membuat hipotesis bahwa dalam diri manusia terdapat hierarki dari lima kebutuhan. Dasar teori kebutuhan Maslow adalah sebagai berikut:

1. Kebutuhan fisiologi (physiological needs)

2. Kebutuhan rasa aman dan keselamatan (safety and security needs)

3. Kebutuhan social (social needs)

4. Kebutuhan penghargaan (esteem or status needs)

5. Kebutuhan aktualisasi diri (self actualization needs)

\section{Return}

Return adalah keuntungan yang diperoleh oleh perusahaan, individu, dan institusi dari hasil kebijakan investasi yang dilakukannya. Menurut Jones (dalam Poppy, 2010:52) return teridiri dari dua komponen, yaitu:

1. Yield merupakan persentase penerimaan kas periodik terhadap harga investasi periode tertentu dari suatu investasi. Untuk saham, yield adalah persentase dividen terhadap harga saham periode sebelumnya. Untuk obligasi, yield adalah persentase bunga pinjaman yang diperoleh terhadap harga obligasi periode sebelumnya.

2. Capital gain (loss) merupakan selisih dari harga investasi sekarang relatif dengan harga periode yang lalu. Jika harga investasi sekarang lebih tinggi dari harga investasi periode lalu, ini berarti terjadi keuntungan modal (capital gain). Sebaliknya, jika harga investasi sekarang lebih rendah dari harga investasi periode lalu disebut capital loss.

Menurut Jogiyanto (dalam Daniel, 2014:381) return merupakan hasil yang diperoleh dari penanaman modal dalam sebuah investasi. Return dapat berupa return realisasi (realized return, dihitung menggunakan data historis) yang sudah terjadi atau return ekspektasi (expected return) yang belum terjadi tetapi diharapkan akan terjadi di masa mendatang.

\section{Risiko}

Joel G. Siegel dan Jae K. Shim (dalam Poppy, 2010:63) mendefinisikan risiko pada 3 hal, yaitu; (1) keadaan yang mengarah kepada sekumpulan hasil khusus, 
hasilnya dapat diperoleh dengan kemungkinan yang telah diketahui oleh pengambil keputusan, (2) variasi dalam keuntungan, penjualan, atau variabel keuangan lainnya, dan (3) kemungkinan dari sebuah masalah keuangan yang mempengaruhi kinerja operasi perusahaan atau posisi keuangan, seperti risiko ekonomi, ketidakpastian politik, dan masalah industrI. Jones mendefinisikan risiko ssebagai variabilitas, dari perbedaan outcome investasi yang diterima dengan diekspektasikan.

\section{Pengetahuan Investasi}

Menurut Kusmawati (dalam Malik, 2017:74) dalam penelitiannya menyatakan bahwa untuk melakukan investasi di pasar modal diperlukan pengetahuan yang cukup, pengalaman serta naluri bisnis untuk menganalisis efek-efek mana saja yang akan dibeli. Pengetahuan yang memadai sangat diperlukan, seperti pada instrumen investasi saham, hal-hal yang sangat penting untuk diketahui adalah bagaimana menilai kinerja perusahaan yang bersangkutan untuk beberapa tahun belakangan. Pengetahuan investasi sangat diperlukan untuk menghindari terjadinya kerugian saat berinvestasi di pasar modal. Pengetahuan investasi juga sangat diperlukan untuk memperoleh return yang maksimal dari investasi yang dilakukan. Untuk mengembangkan lebih luas lagi minat investor selain pengetahuan, faktor persepsi investor terhadap pasar modal syariah.

Pemahaman mengenai investasi sangat diperlukan oleh seseorang untuk melakukan investasi. Apalagi mengenai dasar - dasar investasi seperti jenis-jenis investasi, keuntungan dari melakukan investasi, serta resiko yang diperoleh ketika melakukan investasi sehingga dapat digunakan sebagai pengambilan keputusan apakah akan berinvestasi atau tidak. Selain itu, juga perlu adanya pengalaman untuk menganalisa saham-saham yang mana saja yang akan dibeli, Halim (dalam Aminatun Nisa, 2017:25). Pengetahuan-pengetahuan tersebut diperlukan agar dapat terhindar dari terjadinya kerugian pada saat berinvestasi di pasar modal.

\section{Modal Minimal Investasi}

Saat ini Bursa Efek Indonesia (BEI) selaku pengelola pasar modal di Indonesia telah mengeluarkan peraturan perubahan satuan perdagangan dan fraksi harga yang tertera pada Surat Keputusan Nomor: Kep-00071/BEI/11-2013, surat keputusan tersebut merubah satuan perdagangan saham dalam 1 lot yang awalnya 500 lembar menjadi 100 dengan harga minimal saham yang diperdagangkan di BEI adalah Rp 50,- per lembar, dengan adanya kebijakan ini diharapkan membawa perubahan sehingga dapat menarik minat investor di pasar modal, (idx.co.id).

Disisi lain syarat yang ditawarkan untuk membuka account di sebuah sekuritas sebagai lembaga resmi yang menjadi perantara antara satu investor dengan investor lain, memiliki ketentuan masing-masing akan modal minimal yang harus dideposit ketika membuka account, saat ini di beberapa sekuritas dana awal yang harus kita setor hanya sebesar Rp 100.000,-.Modal yang kita setor ketika membuka account tidak harus dibelanjakan seluruhnya, beberapa saat setelah proses pembukaan account selesai, kita dapat mentransfer kembali sebagian dari 
modal yang di setor, dan menyisakan sejumlah yang ingin di investasikan saja.Menurut Halim, (dalam Haris Nandar, 2018:189) mengatakan bahwa penanaman modal di suatu perusahaan diharapkan akan memperoleh keuntungan pada masa yang akan datang. Syarat berinvestasi di pasar modal saat ini semakin mudah, salah satunya adalah modal minimal untuk berinvestasi yaitu sebesar Rp100.000, sehingga sangat memungkinkan bagi mahasiswa untuk berinvestasi di pasar modal.

\section{Manfaat Investasi}

Menurut CSD (dalam Dasriyan 2018:180) ada lima manfaat dalam investasi yang diperlu diketahui sebagai calon investor adalah:

a. Potensi Penghasilan Jangka Panjang

Secara historis, investasi yang memiliki beberapa risiko modal, entah itu risiko default pada obligasi korporasi, atau risiko penurunan harga saham telah memberi banyak manfaat pada para investor. Tentu saja tidak ada jaminan mengenai hal ini. Jadi, walaupun uang tunai memang lebih aman dibandingkan saham, pada jangka panjang saham bisa menghasilkan potensi pertumbuhan yang signifikan. Setiap volatilitas di pasar saham kadang-kadang dapat merupakan peluang bagi manajer investasi yang ingin membeli saham murah.

b. Mengungguli Inflasi

Agar tabungan anda bisa tumbuh secara nyata dari waktu ke waktu, tabungan tersebut perlu mendapatkan tingkat pengembalian setelah pajak yang lebih besar daripada tingkat inflasi. Dengan suku bunga rendah seperti saat ini, menemukan rekening tabungan yang memberikan pengembalian di atas tingkat inflasi bisa sangat sulit sehingga sangat layak bagi anda mempertimbangkan investasi yang memiliki potensi untuk mengalahkan inflasi.

c. Memberikan Penghasilan Tetap

Jika anda mendekati atau berada di masa pensiun, anda akan mencari penghasilan tetap untuk biaya hidup sehari-hari. Berbagai investasi termasuk, ekuitas, obligasi dan properti dapat memberikan tingkat penghasilan yang tetap dan menarik, yang seringkali lebih tinggi dari tingkat inflasi.

d. Bisa Menyesuaikan Dengan Perubahan Kebutuhan

Portofolio investasi dapat dirancang untuk mencapai tujuan yang berbeda saat anda menjalani hidup. Misalnya, sikap anda terhadap risiko dapat berubah saat anda menjadi lebih tua, dan dengan perencanaan yang matang, sangat mungkin bagi anda untuk menyesuaikan portofolio anda agar bisa sesuai dengan perubahan tujuan anda. Jika anda memiliki jangka waktu yang panjang untuk investasi, anda mungkin ingin berinvestasi pada jenis investasi yang potensi pertumbuhan atau berinvestasi di sektor yang lebih berisiko seperti ekuitas swasta di mana tabungan anda bisa mempengaruhi fluktuasi pasar jangka pendek. Jika anda mendekati pensiun, anda mungkin lebih ingin berinvestasi pada investasi yang lebih berfokus pada pendapatan.

e. Anda Bisa Berinvestasi Sesuai Dengan Keadaan Keuangan Anda

Keadaan keuangan anda akan berubah dari waktu ke waktu, tetapi anda dapat mengubah cara anda berinvestasi sesuai dengan hal tersebut. Jika anda punya uang, anda bisa langsung berinvestasi karena semakin cepat anda memulai, 
semakin lama investasi anda akan berkembang. Atau, investasi dengan jumlah yang rutin setiap bulannya dapat membantu mengatasi fluktuasi kinerja pasar modal. Hal ini bisa sangat bermanfaat dalam pasar yang bergejolak.

\section{METODE PENELITIAN}

\section{Tempat dan Waktu Penelitian}

Penelitian ini dilaksanakan di Universitas swasta yang ada di Kota Bengkulu. Objek penelitian ini adalah mahasiswa akuntansi. Waktu penelitian yakni selama satu bulan (1 Desember - 31 Desember 2019).

\section{Jenis Penelitian}

Penelitian ini menggunakan metode kuantitatif untuk mengamati, mengumpulkan informasi, dan menyajikan analisis hasil penelitian. Karena pada penelitian ini peneliti menggunakan ilmu pengetahuan atau teori yang pernah diteliti oleh peneliti lain sehingga banyak memiliki acuan kepustakaan, variabel diketahui dan teori yang tersedia. Menurut Sugiyono (2015:35) metode kuantitatif adalah metode penelitian yang berlandaskan pada filsafat positivisme, digunakan untuk meneliti pada populasi atau sampel tertentu, pengumpulan data menggunakan instrument penelitian, analisis data bersifat kuantitatif/statistik, dengan tujuan untuk menguji hipotesis yang telah ditetapkan.

\section{Populasi dan Sampel Populasi}

Populasi menurut Umar Sekaran (2017:53) adalah kelompok orang, kejadian, atau hal-hal menarik di mana peneliti ingin membuat opini (berdasarkan statistik sampel). Populasi dalam penelitian ini adalah mahasiswa akuntansi di Universitas Muhammadiyah Bengkulu, Universitas Prof. DR. Hazairin, SH, dan Universitas Dehasen.

Tabel 3.1

Distribusi Mahasiswa Akuntansi

\begin{tabular}{|c|c|c|}
\hline No & Universitas & $\begin{array}{c}\text { Jumlah Mahasiswa } \\
\text { Akuntansi }\end{array}$ \\
\hline 1 & Univ. Muhammadiyah Bengkulu & 789 \\
\hline 2 & Univ. Prof. DR. Hazairin, SH & 130 \\
\hline 3 & Univ. Dehasen & 133 \\
\hline \multicolumn{2}{|c|}{ Total Mahasiswa Akuntansi } & 1052 \\
\hline
\end{tabular}

\section{Sampel}

Sampel menurut Sugiyono (2015:149)) adalah bagian dari jumlah dan karakteristik yang dimiliki oleh populasi tersebut. Metode penentuan jumlah sampel yang digunakan pada penelitian ini adalah dengan menggunakan tabel ukuran sampel yang dikembangkan oleh Isaac dan Michael, (dalam Sugiyono, 2015:161). Metode ini sangat mudah digunakan karena cukup dengan membaca tabel berdasarkan jumlah populasi yang diiginkan dan tingkat kesalahan yang akan digunakan $(1 \%$, 5\% dan 10\%). Semakin besar tingkat kesalahan yang digunakan maka jumlah sampel yang digunakan akan semakin sedikit. Jika 
jumlah sampel semakin mendekati populasi, maka tingkat kesalahan dalam mengeneralisasikan kesimpulan sampel pada populasi akan semakin kecil.

Table 3.2

Jumlah sampel dari populasi metode Isaac dan Michael

\begin{tabular}{|c|c|c|c|}
\hline \multirow{2}{*}{ Populasi } & \multicolumn{3}{|c|}{ Signifikasi } \\
\cline { 2 - 4 } & $1 \%$ & $5 \%$ & $10 \%$ \\
\hline 900 & 382 & 251 & 208 \\
\hline 950 & 391 & 255 & 211 \\
\hline 1000 & 399 & 258 & 213 \\
\hline 1100 & 414 & 265 & 217 \\
\hline 1200 & 427 & 270 & 221 \\
\hline
\end{tabular}

Sumber : Sugiyono. 2015. Metode penelitian

Penelitian ini menggunakan tingkat kesalahan 5\% untuk ukuran sampel agar jumlah sampel yang eror atau tidak sesuai dengan kualifikasi tidak terlalu banyak dan jugan tidak terlalu sedikit. Berdasarkan tabel diatas, jumlah sampel yang dibutuhkan berdasarkan tabel populasi yang mendekati $\mathrm{N}=1052$ adalah $265(\mathrm{~N}=$ 1100). Jumlah sampel dalam penelitian ini adalah sebanyak 265 mahasiswa

1. $\mathrm{UMB}=789 / 1052 \times 265=199$

2. UNIHAZ $=130 / 1052 \times 265=33$

3. $\underline{\text { UNIVED }=133 / 1052 \times 265=33}$

Jumlah sampel = $=265$ Mahasiswa

\section{Teknik Pengumpulan Data}

Teknik pengumpulan data yang digunakan yaitu kuisioner. Kuesioner adalah daftar pertanyaan tertulis yang telah di rumuskan sebelumnya di mana responden akan mencatat jawaban mereka, biasanya dalam alternatif yang didefinisikan dengan jelas, (Umar Sekaran, (2017:170). kuesioner ini digunakan untuk memperoleh data dari responden mengenai faktor-faktor yang mempengaruhi minat mahasiswa untuk berinvestasi di pasar modal.

\section{Uji Hipotesis}

1. Uji T

Uji T digunakan untuk mengetahui hipotesis diterima atau tidak. Pengambilan kesimpulan adalah jika $\mathrm{t}$ hitung $>\mathrm{t}$ table atau probabilitas < tingkat signifikansi (Sig $\leq$ 0,05), maka Ha diterima dan Ho ditolak, jadi variabel independen berpengaruh terhadap variabel dependen. Sebaliknya jika $t$ hitung $<\mathrm{t}$ table atau probabilitas > tingkat signifikansi $(\mathrm{Sig}>0,05)$, maka Ha ditolak dan Ho diterima.

2. Uji F

Uji $\mathrm{F}$ dilakukan untuk menunjukkan apakah semua variabel independen yang dimasukkan dalam model regresi mempunyai pengaruh secara bersama-sama atau simultan terhadap variabel dependen. Uji ini dilakukan dengan membandingkan nilai signifikansi dengan nilai $\alpha$ (5\%), dengan ketentuan sebagai berikut:

Jika nilai Sig $<\alpha$ maka H0 ditolak

Jika nilai Sig $>\alpha$ maka H0 diterima 


\section{Analisis Regresi Berganda}

Regresi berganda digunakan untuk mengetahui arah dan besarnya pengaruh dari variabel bebas yang jumalahnya lebih dari satu terhadap variabel terikatnya, (Siti Nurhasanah, 2016:104).

Persamaan dalam regresi berganda adalah sebagai berikut:

$$
\mathrm{Y}=a+\mathrm{b}_{1} \mathrm{X}_{1}+\mathrm{b}_{2} \mathrm{X}_{2}+\mathrm{b}_{3} \mathrm{X}_{3}+\mathrm{b}_{4} \mathrm{X}_{4}+\mathrm{b}_{5} \mathrm{X}_{5}+\mathrm{b}_{6} \mathrm{X}_{6}+\mathrm{e}
$$

Keterangan:

$$
\begin{aligned}
& Y=\text { Minat investasi. } \\
& X_{1}=\text { Pengetahuan investasi } \\
& X_{2}=\text { Motivasi investasi } \\
& X_{3}=\text { Modal minimal investasi } \\
& X_{4}=\text { Return investasi } \\
& X_{5}=\text { Risiko investasi } \\
& X_{6}=\text { Manfaat investasi. } \\
& a=\text { Konstanta. } \\
& b=\text { Koefisien linier berganda. } \\
& \text { e }=\text { tingkat kesalahan. }
\end{aligned}
$$

\section{HASIL PENELITIAN DAN PEMBAHASAN \\ Gambaran Umum Penelitian}

Galeri Investasi Bursa Efek Indonesia Universitas Muhammadiyah Bengkulu yang kemudian disebut GI UMB berdiri pada tanggal 20 Maret 2018 yang merupakan kerjasama antara tiga instansi yaituUniversitas Muhammadiyah Bengkulu, Phintraco Sekuritas dan Bursa Efek Indonesia. Galeri Investasi Bursa Efek Indonesia Universitas Prof. Dr. Hazairin, SH yang kemudian disebut GI UNIHAZ berdiri pada tanggal 9 September 2017 yang merupakan kerjasama antara tiga instansi yaitu, Universitas Prof. Dr. Hazairin, SH, Phintraco Sekuritas dan Bursa Efek Indonesia.

Galeri Investasi Bursa Efek Indonesia Universitas Dehasen yang kemudian disebut GI DEHASEN berdiri pada tanggal 12 Agustus 2017 yang merupakan kerjasama antara tiga instansi yaitu Universitas Dehasen, Phintraco Sekuritas dan Bursa Efek Indonesia. Galeri Investasi merupakan pojok bursa yang memberikan kemudahan akses kepada masyarakat untuk berinvestasi di pasar modal selain fungsi sebagai media edukasi pasar modal. Operasional Galeri Investasi dijalankan oleh Kelompok Studi Pasar Modal yang disebut KSPM yang mana merupakan suatu kelompok mahasiswa yang mengkaji tentang Pasar Modal. Penelitian ini mengenai faktor-faktor yang mempengaruhi minat mahasiswa untuk berinvestasi di paar modal. Penelitian ini dilakukan pada mahasiswa akuntansi di Universitas swasta yang ada di Kota Bengkulu. Data hasil penelitian ini terdiri dari enam variabel bebas yakni Pengetahuan (X1), Motivasi (X1), Modal minimal (X3), Return (X4), Risiko (X5), dan Manfaat (X6) serta satu variabel terikat minat binvestasi di pasar modal (Y). Hasil perolehan data pada penelitian ini berasal dari data primer, yaitu data yang dikumpulkan dari penyebaran kuesioner kepada mahasiswa akuntansi di Univesitas Swasta yang ada di Kota Bengkulu. Kuesioner 
penelitian dibuat menggunakan aplikasi Google Form dan disebarkan secara daring melalui media sosial WhatsApp.

\section{Uji Hipotesis}

\section{Uji Pengaruh Parsial (Uji t)}

Tabel 4.11

Uji Pengaruh Parsial (Uji t)

\begin{tabular}{|c|c|c|c|c|c|c|}
\hline \multicolumn{7}{|c|}{ Coefficients $^{\mathbf{a}}$} \\
\hline \multirow{3}{*}{\multicolumn{2}{|c|}{ Model }} & \multirow{2}{*}{\multicolumn{2}{|c|}{ Unstandardized Coefficients }} & \multirow{3}{*}{$\begin{array}{c}\text { Standardized } \\
\text { Coefficients }\end{array}$} & \multirow[b]{3}{*}{$\mathrm{t}$} & \multirow[b]{3}{*}{ Sig. } \\
\hline & & & & & & \\
\hline & & $\mathrm{B}$ & Std. Error & & & \\
\hline \multirow[t]{7}{*}{1} & (Constant) & ,682 & 1,119 & & ,609 &, 543 \\
\hline & Pengetahuan & ,178 & ,051 & ,198 & 3,484 & ,001 \\
\hline & Motivasi & ,083 & ,042 & ,091 & 1,976 & ,049 \\
\hline & ModalMinimal & ,133 & ,045 & ,163 & 2,989 &, 003 \\
\hline & Return & 271 & ,069 & 241 & 3,944 &, 000 \\
\hline & Risiko & ,078 & ,028 & , 140 & 2,818 & ,005 \\
\hline & Manfaat & ,134 & ,040 & ,190 & 3,362 & ,001 \\
\hline \multicolumn{7}{|c|}{ a. Dependent Variable: Minat } \\
\hline
\end{tabular}

Sumber: Lampiran 6

1. Berdasarkan tabel 4.9 di atas diketahui bahwa pada variabel pengetahuan diperoleh nilai $t_{\text {hitung }}=3,484$ dan probabilitas sebesar 0,001 , jika dibandingkan dengan $t_{\text {tabel }} 1,969\left(t_{\text {tabel }}\right.$ tersaji di lampiran) maka $t_{\text {hitung }}>t_{\text {tabel }}$ dan $\rho<0,05$. Hal ini menunjukkan bahwa H1 diterima, artinya variabel pengetahuan berpengaruh positif dan signifikan terhadap minat berinvestasi pada mahasiswa akuntansi di universitas swasta yang ada di kota Bengkulu.

2. Variabel motivasi diperoleh nilai $t_{\text {hitung }}=1,976$ dan probabilitas sebesar 0,049 , jika dibandingkan dengan $t_{\text {tabel }} 1,969$ ( $t_{\text {tabel }}$ tersaji di lampiran) maka $t_{\text {hitung }}>$ $\mathrm{t}_{\text {tabel }}$ dan $\rho<0,05$. Hal ini menunjukkan bahwa $\mathrm{H} 2$ diterima, artinya variabel motivasi berpengaruh positif dan signifikan terhadap minat berinvestasi pada mahasiswa akuntansi di universitas swasta yang ada di kota Bengkulu.

3. Variabel modal minimal diperoleh nilai $t_{\text {hitung }}=2,989$ dan probabilitas sebesar 0,003, jika dibandingkan dengan $t_{\text {tabel }} 1,969\left(t_{\text {tabel }}\right.$ tersaji di lampiran) maka $t_{\text {hitung }}>t_{\text {tabel }}$ dan $\rho<0,05$. Hal ini menunjukkan bahwa $\mathrm{H} 3$ diterima, artinya variabel modal minimal berpengaruh positif dan signifikan terhadap minat berinvestasi pada mahasiswa akuntansi di universitas swasta yang ada di kota Bengkulu.

4. Variabel return diperoleh nilai $t_{\text {hitung }}=3,944$ dan probabilitas sebesar 0,000 , jika dibandingkan dengan $t_{\text {tabel }} 1,969\left(t_{\text {tabel }}\right.$ tersaji di lampiran) maka $t_{\text {hitung }}>t_{\text {tabel }}$ dan $\rho<0,05$. Hal ini menunjukkan bahwa $\mathrm{H} 4$ diterima, artinya variabel return berpengaruh positif dan signifikan terhadap minat berinvestasi pada mahasiswa akuntansi di universitas swasta yang ada di kota Bengkulu.

5. Variabel risiko diperoleh nilai $t_{\text {hitung }}=2,818$ dan probabilitas sebesar 0,005 , jika dibandingkan dengan $t_{\text {tabel }} 1,969\left(t_{\text {tabel }}\right.$ tersaji di lampiran) maka $t_{\text {hitung }}>t_{\text {tabel }}$ dan $\rho<0,05$. Hal ini menunjukkan bahwa H5 diterima, artinya variabel risiko berpengaruh positif dan signifikan terhadap minat berinvestasi pada mahasiswa akuntansi di universitas swasta yang ada di kota Bengkulu.

6. Variabel manfaat diperoleh nilai $t_{\text {hitung }}=3,362$ dan probabilitas sebesar 0,001 , jika dibandingkan dengan $t_{\text {tabel }} 1,969$ ( $t_{\text {tabel }}$ tersaji di lampiran) maka $t_{\text {hitung }}>$ 
$\mathrm{t}_{\text {tabel }}$ dan $\rho<0,05$. Hal ini menunjukkan bahwa H6 diterima, artinya variabel manfaat berpengaruh positif dan signifikan terhadap minat berinvestasi pada mahasiswa akuntansi di universitas swasta yang ada di kota Bengkulu.

\section{Uji Pengaruh Simultan (Uji F)}

Tabel 4.12

Uji Pengaruh Simultan (Uji F)

\begin{tabular}{|ll|r|r|r|r|r|}
\multicolumn{7}{|c|}{ ANOVA $^{\mathbf{b}}$} \\
\hline Model & & Sum of Squares & \multicolumn{1}{c|}{ Df } & Mean Square & \multicolumn{1}{c|}{ F } & \multicolumn{1}{c|}{ Sig. } \\
\hline 1 & Regression & 545,538 & 6 & 90,923 & 38,175 &, $000^{\text {a }}$ \\
& Residual & 614,484 & 258 & 2,382 & & \\
& Total & 1160,023 & 264 & & & \\
\hline
\end{tabular}

a. Predictors: (Constant), Manfaat, Motivasi, Risiko, ModalMinimal, Pengetahuan, Return

b. Dependent Variable: Minat

Sumber: Lampiran 6

Berdasarkan tabel 4.10 di atas, hasil uji $\mathrm{F}$ dapat dilihat dari nilai $\mathrm{F}_{\text {hitung }}$ pada tabel ANOVA yaitu diperoleh $F_{\text {hitung }}$ sebesar 38,175 dan sig. 0,000. Hasil ini lebih besar jika dibandingkan dengan $F_{\text {tabel }}=2,134$ ( $F_{\text {tabel }}$ tersaji di lampiran). Sehingga dapat disimpulkan bahwa $\mathrm{H} 7$ diterima, artinya terdapat pengaruh yang positif dan signifikan. Variabel pengetahuan, motivasi, modal minimal, return, risiko, dan manfaat secara simultan berpengaruh terhadap minat berinvestasi pada mahasiswa akuntansi di universitas swasta yang ada di Kota Bengkulu.

\section{Regresi Linear Berganda}

Tabel 4.13

Regresi Linear Berganda

Coefficients $^{\mathrm{a}}$

\begin{tabular}{|c|c|c|c|c|c|c|}
\hline \multirow{2}{*}{\multicolumn{2}{|c|}{ Model }} & \multicolumn{2}{|c|}{$\begin{array}{l}\text { Unstandardized } \\
\text { Coefficients }\end{array}$} & \multirow{2}{*}{$\begin{array}{c}\begin{array}{c}\text { Standardized } \\
\text { Coefficients }\end{array} \\
\text { Beta }\end{array}$} & \multirow[b]{2}{*}{$\mathrm{t}$} & \multirow[b]{2}{*}{ Sig. } \\
\hline & & B & Std. Error & & & \\
\hline & (Constant) & ,682 & 1,119 & & ,609 & ,543 \\
\hline & Pengetahuan & , 178 & 051 & , 198 & 3,484 & 001 \\
\hline & Motivasi & ,083 &, 042 & ,091 & 1,976 & ,049 \\
\hline & ModalMinimal & ,133 & 045 &, 163 & 2,989 & ,003 \\
\hline & Return & ,271 & ,069 & ,241 & 3,944 &, 000 \\
\hline & Risiko & ,078 & ,028 & , 140 & 2,818 & ,005 \\
\hline & Manfaat & , 134 & 040 & , 190 & 3,362 & ,001 \\
\hline
\end{tabular}

a. Dependent Variable: Minat

Sumber: Lampiran 6

Berdasarkan Tabel 4.8, diperoleh persamaan regresi linear bergandasebagai berikut:

$\mathrm{Y}=0,682+0,178 \mathrm{X} 1+0,083 \mathrm{X} 2+0,133 \mathrm{X} 3+0,271 \mathrm{X} 4+0,078 \mathrm{X} 5+0.134 \mathrm{X} 6+\mathrm{e}$

Berdasarkan persamaan diatas, maka dapat diinterpretasikan sebagai berikut: 
1. Persamaan di atas menunjukkan nilai konstanta bernilai positif sebesar 0,682 artinya apabila variabel pengetahuan, motivasi, modal minimal, return, risiko, dan manfaat dianggap konstan $=0$. Maka variabel pengetahuan, motivasi, modal minimal, return, risiko, dan manfaat berpengaruh terhadap minat investasi sebesar 0,682 .

2. Koefisien regresi variabel pengetahuan bernilai positif sebesar 0,178 . Hal ini berarti bahwa jika variabel pengetahuan ditingkatkan satu satuan dengan catatan variabel motivasi, modal minimal, return, risiko, dan manfaat dianggap konstan, maka akan meningkatkan minat mahasiswa untuk berinvestasi di pasar modal adalah sebesar 0,178 .

3. Koefisien regresi variabel motivasi bernilai positif sebesar 0,083. Hal ini berarti bahwa jika variabel motivasi ditingkatkan satu satuan dengan catatan variabel pengetahuan, modal minimal, return, risiko, dan manfaat dianggap konstan, maka akan meningkatkan minat mahasiswa untuk berinvestasi di pasar modal adalah sebesar 0,083.

4. Koefisien regresi variabel modal minimal bernilai positif sebesar 0,133 . Hal ini berarti bahwa jika variabel modal minimal ditingkatkan satu satuan dengan catatan variabel pengetahuan, motivasi, return, risiko, dan manfaat dianggap konstan, maka akan meningkatkan minat mahasiswa untuk berinvestasi di pasar modal adalah sebesar 0,133 .

5. Koefisien regresi variabel return bernilai positif sebesar 0,271. Hal ini berarti bahwa jika variabel return ditingkatkan satu satuan dengan catatan variabel pengetahuan, motivasi, modal minimal, risiko, dan manfaat dianggap konstan, maka akan meningkatkan minat mahasiswa untuk berinvestasi di pasar modal adalah sebesar 0,271.

6. Koefisien regresi variabel risiko bernilai positif sebesar 0,078. Hal ini berarti bahwa jika variabel risiko ditingkatkan satu satuan dengan catatan variabel pengetahuan, motivasi, modal minimal, return, dan manfaat dianggap konstan, maka akan meningkatkan minat mahasiswa untuk berinvestasi di pasar modal adalah sebesar 0,078 .

7. Koefisien regresi variabel manfaat bernilai positif sebesar 0,134 . Hal ini berarti bahwa jika variabel manfaat ditingkatkan satu satuan dengan catatan variabel pengetahuan, motivasi, modal minimal, return, dan risiko dianggap konstan, maka akan meningkatkan minat mahasiswa untuk berinvestasi di pasar modal adalah sebesar 0,134 .

\section{PEMBAHASAN}

\section{Pengaruh Pengetahuan Terhadap Minat Berinvestasi di Pasar Modal}

Hasil pengujian hipotesis secara parsial (uji t) menunjukkan bahwa variabel pengetahuan (X1) berpengaruh positif dan signifikan terhadap minat berinvestasi (Y). Hal ini dinyatakan berdasarkan hasil uji t terhadap minat mahasiswa berinvestasi di pasar modal dimana nilai signifikansinya $0,001<0,05$.

Maka dapat dijelaskan bahwa variabel pengetahuan memiliki pengaruh terhadap minat investasi di pasar modal. Penelitian ini didukung dengan teori Menurut Baihaqi (2016), pengetahuan adalah informasi yang telah diorganisasikan di dalam memori sebagai bagian dari sebuah sistem atau jaringan informasi yang 
terstruktur. Informasi yang diterima oleh individu baik dari aktivitas pembelajaran di kampus, pelatihan-pelatihan, seminar-seminar seperti seminar pasar modal merupakan bentuk pembelajaran bagi individu yang kemudian akan menumbuhkan minat bagi individu tersebut.

Hasil penelitian ini sejalan dengan penelitian yang dilakukan Rizki (2017), menyatakan bahwa variabel pengetahuan berpengaruh terhadap minat berinvestasi pada mahasiswa dimana niilai signifikansinya $0,000<0,05$. Hal ini juga sejalan dengan penelitian yang dilakukan Nensy (2018), menyatakan bahwa variabel pengetahuan berpengaruh terhadap minat berinvestasi pada mahasiswa dimana niilai signifikansinya $0,017<0,05$. Meski demikian, pernyataan sebaliknya dinyatakan pada penelitian lain yakni pada Malik (2017), menyatakan bahwa variabel pengetahuan tidak berpengaruh terhadap minat berinvestasi pada mahasiswa dimana niilai signifikansinya $0,758>0,05$.

\section{Pengaruh Motivasi Terhadap Minat Berinvestasi di Pasar Modal}

Hasil pengujian hipotesis secara parsial (uji t) menunjukkan bahwa variabel motivasi (X2) berpengaruh positif dan signifikan terhadap minat berinvestasi (Y). Hal ini dinyatakan berdasarkan hasil uji t terhadap minat mahasiswa berinvestasi di pasar modal dimana nilai signifikansinya $0,049<0,05$. Maka dapat dijelaskan bahwa variabel motivasi memiliki pengaruh terhadap minat investasi di pasar modal. Penelitian ini didukung dengan teori Menurut Slameto (2010), motivasi adalah keadaan dalam pribadi seseorang yang mendorong keinginan individu untuk melakukan kegiatan-kegiatan tertentu guna mencapai tujuan. Motivasi yang ada pada seseorang akan mewujudkan suatu perilaku yang diarahkan pada tujuan mencapai sasaran kepuasan.

Hasil penelitian ini sejalan dengan penelitian yang dilakukan Rizki (2017), menyatakan bahwa variabel motivasi berpengaruh terhadap minat berinvestasi pada mahasiswa dimana niilai signifikansinya $0,000<0,05$. Hal ini juga sejalan dengan penelitian yang dilakukan Malik (2017), menyatakan bahwa variabel motivasi berpengaruh terhadap minat berinvestasi pada mahasiswa dimana niilai signifikansinya $0,000<0,05$. Meski demikian, pernyataan sebaliknya dinyatakan pada penelitian lain yakni pada Nensy (2018), menyatakan bahwa variabel motivasi tidak berpengaruh terhadap minat berinvestasi pada mahasiswa dimana niilai signifikansinya $0,494>0,05$.

\section{Pengaruh Modal Minimal Terhadap Minat Berinvestasi di Pasar Modal}

Hasil pengujian hipotesis secara parsial (uji t) menunjukkan bahwa variabel modal minimal (X3) berpengaruh positif dan signifikan terhadap minat berinvestasi (Y). Hal ini dinyatakan berdasarkan hasil uji t terhadap minat mahasiswa berinvestasi di pasar modal dimana nilai signifikansinya $0,003<0,05$. Maka dapat dijelaskan bahwa variabel modal minimal memiliki pengaruh terhadap minat investasi di pasar modal. Responden sangat memperhatikan modal awal yang dikeluarkan saat melakukan investasi hal ini berkaitan dengan kestabilan keuangan bagi calon investor. Saat ini BEI gentar melakukan kampanye guna mengajak masyarakat 
untuk berinvestasi di pasar modal dengan hanya berbekal Rp.100.000,00 bisa mendapatkan 1 lot saham yang harganya Rp 1.000/lembar. Investasi yang ditawarkan berupa saham dan reksa dana, (idx.co.id).

Hasil penelitian ini sejalan dengan penelitian yang dilakukan Riyadi (2016), menyatakan bahwa variabel modal minimal berpengaruh terhadap minat berinvestasi pada mahasiswa dimana niilai signifikansinya $0,010<0,05$. Hal ini juga sejalan dengan penelitian yang dilakukan Aminatun Nisa (2017), menyatakan bahwa variabel modal minimal berpengaruh terhadap minat berinvestasi pada mahasiswa dimana niilai signifikansinya $0,023<0,05$. Meski demikian, pernyataan sebaliknya dinyatakan pada penelitian lain yakni pada Nensy (2018), menyatakan bahwa variabel modal minimal tidak berpengaruh terhadap minat berinvestasi pada mahasiswa dimana niilai signifikansinya $0,877>0,05$.

\section{Pengaruh Return Terhadap Minat Berinvestasi di Pasar Modal}

Hasil pengujian hipotesis secara parsial (uji t) menunjukkan bahwa variabel return (X4) berpengaruh positif dan signifikan terhadap minat berinvestasi (Y). Hal ini dinyatakan berdasarkan hasil uji t terhadap minat mahasiswa berinvestasi di pasar modal dimana nilai signifikansinya $0,000<0,05$. Maka dapat dijelaskan bahwa variabel return memiliki pengaruh terhadap minat investasi di pasar modal. Penelitian ini didukung dengan teori Menurut Poppy (2010), mengatakan return adalah keuntungan yang diperoleh oleh perusahaan, individu dan institusi dari hasil kebijakan investasi yang dilakukannya. Semakin tinggi return saham maka semakin baik investasi yang dilakukan karena dapat menghasilkan keuntungan, sebaliknya semakin return atau bahkan negatif maka semakin buruk hasil investasi yang dilakukan.

Hasil penelitian ini sejalan dengan penelitian yang dilakukan Hermanto (2017), menyatakan bahwa variabel return berpengaruh terhadap minat berinvestasi pada mahasiswa dimana niilai signifikansinya $0,000<0,05$. Hal ini juga sejalan dengan penelitian yang dilakukan Nensy (2018), menyatakan bahwa variabel return berpengaruh terhadap minat berinvestasi pada mahasiswa dimana niilai signifikansinya $0,037<0,05$. Meski demikian, pernyataan sebaliknya dinyatakan pada penelitian lain yakni pada Riyadi (2016), menyatakan bahwa variabel return tidak berpengaruh terhadap minat berinvestasi pada mahasiswa dimana niilai signifikansinya $0,648>0,05$.

\section{Pengaruh Risiko Terhadap Minat Berinvestasi di Pasar Modal}

Hasil pengujian hipotesis secara parsial (uji t) menunjukkan bahwa variabel risiko (X5) berpengaruh positif dan signifikan terhadap minat berinvestasi (Y). Hal ini dinyatakan berdasarkan hasil uji t terhadap minat mahasiswa berinvestasi di pasar modal dimana nilai signifikansinya $0,005<0,05$. Maka dapat dijelaskan bahwa variabel risiko memiliki pengaruh terhadap minat investasi di pasar modal. Penelitian ini didukung dengan teori Menurut Poppy (2010) risiko adalah kemungkinan terjadinya kerugian atau return negative dari suatu investasi. Semakin tinggi risiko saham maka semakin baik investasi yang dilakukan karena 
dapat menghasilkan return (keuntungan), sebaliknya semakin rendah risiko maka semakin buruk hasil investasi yang dilakukan.

Hasil penelitian ini sejalan dengan penelitian yang dilakukan Lilis Yuliati (2011), menyatakan bahwa variabel risiko berpengaruh terhadap minat berinvestasi pada mahasiswa dimana niilai signifikansinya $0,008<0,05$. Hal ini juga sejalan dengan penelitian yang dilakukan Malik (2017), menyatakan bahwa variabel risiko berpengaruh terhadap minat berinvestasi pada mahasiswa dimana niilai signifikansinya $0,000<0,05$. Meski demikian, pernyataan sebaliknya dinyatakan pada penelitian lain yakni pada Tandio dan Widanaputra (2016), menyatakan bahwa variabel risiko tidak berpengaruh terhadap minat berinvestasi pada mahasiswa dimana niilai signifikansinya $0,213>0,05$.

\section{Pengaruh Manfaat Terhadap Minat Berinvestasi di Pasar Modal}

Hasil pengujian hipotesis secara parsial (uji t) menunjukkan bahwa variabel manfaat (X6) berpengaruh positif dan signifikan terhadap minat berinvestasi (Y). Hal ini dinyatakan berdasarkan hasil uji t terhadap minat mahasiswa berinvestasi di pasar modal dimana nilai signifikansinya $0,001<0,05$. Maka dapat dijelaskan bahwa variabel manfaat memiliki pengaruh terhadap minat investasi di pasar modal. Penelitian ini didukung dengan teori Menurut Tandelilin (2010) Manfaat melakukan investasi di pasar modal dapat dilihat dari sisi investor (yang membeli sekuritas) dan sisi emiten (yang menerbitkan sekuritas). Dari sisi investor, keberaadaan pasar modal diperlukan sebagai alternatif untuk melakukan investasi pada financial asset. Dari sisi emiten, keberadaan pasar modal diperlukan sebagai suatu alternatif untuk menghimpun dana dan eksternal jangka panjang tanpa menggunakan intermediasi keuangan.

Hasil penelitian ini sejalan dengan penelitian yang dilakukan Riyadi (2016), menyatakan bahwa variabel manfaat berpengaruh terhadap minat berinvestasi pada mahasiswa dimana niilai signifikansinya $0,012<0,05$. Hal ini juga sejalan dengan penelitian yang dilakukan Hermanto (2017), menyatakan bahwa variabel manfaat berpengaruh terhadap minat berinvestasi pada mahasiswa dimana niilai signifikansinya $0,006<0,05$. Meski demikian, pernyataan sebaliknya dinyatakan pada penelitian lain yakni pada Nensy (2018), menyatakan bahwa variabel manfaat tidak berpengaruh terhadap minat berinvestasi pada mahasiswa dimana niilai signifikansinya $0,630>0,05$.

\section{KESIMPULAN DAN SARAN}

\section{Kesimpulan}

Berdasarkan analisis data yang telah dilakukan, maka dapat disimpulkan secara keseluruhan dari penelitian ini adalah sebagai berikut:

1. Hasil pengujian signifikansi menunjukkan bahwa terdapat nilai sig sebesar 0,001, $(0,001<0,05)$. Dari hasil nilai tersebut menunjukan bahwa "pengetahuan investasi berpengaruh positif dan signifikan terhadap minat mahasiswa berinvestasi di pasar modal". 
2. Hasil pengujian signifikansi menunjukkan bahwa terdapat nilai sig sebesar $0,049, \quad(0,049<0,05)$. Dari hasil nilai tersebut menunjukan bahwa "motivasi investasi berpengaruh positif dan signifikan terhadap minat mahasiswa berinvestasi di pasar modal".

3. Hasil pengujian signifikansi menunjukkan bahwa terdapat nilai sig sebesar 0,003, $(0,003<0,05)$. Dari hasil nilai tersebut menunjukan bahwa "modal minimal investasi berpengaruh positif dan signifikan terhadap minat mahasiswa berinvestasi di pasar modal".

4. Hasil pengujian signifikansi menunjukkan bahwa terdapat nilai sig sebesar 0,000, $(0,000<0,05)$. Dari hasil nilai tersebut menunjukan bahwa "return investasi berpengaruh positif dan signifikan terhadap minat mahasiswa berinvestasi di pasar modal".

5. Hasil pengujian signifikansi menunjukkan bahwa terdapat nilai sig sebesar $0,005,(0,005<0,05)$. Dari hasil nilai tersebut menunjukan bahwa "risiko investasi berpengaruh positif dan signifikan terhadap minat mahasiswa berinvestasi di pasar modal".

6. Hasil pengujian signifikansi menunjukkan bahwa terdapat nilai sig sebesar 0,001, $(0,001<0,05)$. Dari hasil nilai tersebut menunjukan bahwa "manfaat investasi berpengaruh positif dan signifikan terhadap minat mahasiswa berinvestasi di pasar modal".

7. Hasil pengujian $F_{\text {hitung }}$ adalah sebesar 38,175 dan nilai sig sebesar 0,000, $(0,000<0,05)$, maka disimpulkan bahwa "pengetahuan investasi, motivasi investasi, modal minimal investasi, return investasi, risiko investasi dan manfaat investasi secara simultan berpengaruh positif dan signifikan terhadap minat mahasiswa berinvestasi di pasar modal”.

\section{Saran}

1. Bagi Peneliti Selanjutnya

1. Peneliti selanjutnya disarankan menggunakan sampel yang lebih besar sehingga hasil yang akan dihasilkan lebih meyakinkan.

2. Peneliti selanjutnya dapat menambah jumlah variabel penelitian untuk mengetahui lebih lengkap variabel yang mempengaruhi minat investasi.

3. Peneliti selanjutnya diharapkan membedakan responden mahasiswa yang sudah menjadi investor saham di pasar modal dan mahasiswa yang belum menjadi investor di pasar modal.

2. Bagi Pengelola Galeri Investasi

1. Pengelola Galeri Investasi diharapkan dapat memberikan wawasan atau pelatihan tentang pasar modal kepada mahasiswa sehingga dapat memicu adanya minat untuk berinvestasi di pasar modal.

a. Pengelola Galeri Investasi diharapkan dapat membuat program-program pengenalan terhadap investasi di pasar modal untuk menarik minat mahasiswa untuk berinvestasi pasar modal.

b. Pengelola Galeri Investasi diharapkan dapat memberikan sosialisasi atau membuka stand di tempat umum sehingga dapat menarik perhatian dan minat untuk berinvestasi di pasar modal. 


\section{DAFTAR PUSTAKA}

Ahmad Dahlan Malik. (2017). "Analisis Faktor - Faktor Yang Mempengaruhi Minat Masyarakat Berinvestasi Di Pasar Modal Syariah Melalui Bursa Galeri Investasi UISI”. Jurnal Ekonomi dan Bisnis Islam. Vol. 3, No. 1. Universitas Internasional Semen Indonesia.

Ahmad Ulil Albab Al Umar. (2019). "Pengaruh Manfaat, Pengetahuan Dan Edukasi Terhadap Minat Mahasiswa Dalam Berinvestasi Di Pasar Modal Syariah (Study Kasus Pada Mahasiswa IAIN Salatiga”. Li Falah-Jurnal Studi Ekonomi Dan Bisnis Islam. Volume 4 No.1. P-ISSN: 2541-6545, E-ISSN: 2549-6085.

Aminatun Nisa. Luki Zulaika. (2017). "Pengaruh Pemahaman Investasi, Modal Minimal Investasi dan Motivasi Terhadap Minat Mahasiswa Berinvestasi di Pasar Modal". Jurnal PETA. Vol. 2 No. 2: 22-35. E-ISSN 2528-2581.

Arlin Ferlina. Riswan Kuswardhana. (2017). "Pengaruh Informasi Produk, Resiko Investasi, Kepuasaan Investor dan Minat Mahasiswa Berinvestasi". Jurnal Sekretaris \& Administrasi Bisnis. Volume I, Number 1. E-ISSN: 2580-8095.

Daniel Raditya T, dkk. (2014). "Pengaruh Modal Investasi Minimal di BNI Sekuritas, Return dan Persepsi Terhadap Risiko Pada Minat Investasi Mahasiswa, Dengan Pengahasilan Sebagai Variabel Moderasi”. E-Jurnal Ekonomi dan Bisnis Universitas Udayana 3.7 (2014):377-390. ISSN: 2337-3067.

Haris Nandar, ddk. (2018). "Faktor yang Mempengaruhi Minat Mahasiswa Berinvestasi di Pasar Modal Syariah Melalui Galeri Investasi Iain Zawiyah Cot Kala Langsa". Tesis. KITABAH. Volume 2. No. 2. Universitas Islam Negeri Sumatera Utara Medan.

Imam Ghozali. (2018). "Aplikasi Analisis Multivariate dengan Program IBM SPSS 25". Semarang: Undip.

Lilis Yuliati. (2011). "Faktor-Faktor yang Mempengaruhi Minat Masyarakat Berinvestasi SUKUK". Walisongo .Volume 19, Nomor 1.

M. Baihaqi. (2016). Pengantar Psikologi Kognitif.Bandung: PT Refika Aditama.

Masri Situmorang, dkk. (2014). "Pengaruh Motivasi Terhadap Minat Berinvestasi di Pasar Modal Dengan Pemahaman Investasi dan Usia Sebagai Variabel Moderat". JOM FEKON Vol. 1 No.2.

Poppy Nurmayanti. Novita Indrawati. (2010). "Dasar - Dasar Analisis Investasi dan Portofolio”. Palembang: CitraBooks Indonesia. 
Rizki Chaerul Pajar. (2017). "Pengaruh Motivasi Investasi dan Pengetahuan Investasi Terhadap Minat Investasi di Pasar Modal Pada Mahasiswa FE UNY”. Jurnal Profita Edisi 1. Universitas Negeri Yogyakarta.

Romi Bhakti (Penterjemah), Bodie, dkk. (2014). "Manajemen Portofolio dan Investasi”. McGraw-Hill Education. Jakarta: Salemba Empat.

Sartika Susanti, Muhammad Hasan, dkk, (2018). "Faktor - faktor yang mempengaruhi minat mahasiswa berinvestasi di pasar modal". Prosiding Seminar Nasional Pendidikan Ekonomi. ISBN 978-602-60061-2-7. Universitas Negeri Makasar.

Sugiyono. (2015). "Metode Penelitian Kombinasi (Mixed Methods)". Bandung: ALFABETA.

Totok BudiSantoso \& Nuritomo. (2014). "Bank dan Lembaga Keuangan Lain”. Jakarta: Salemba Empat.

Yon, Kwan Men (Penterjemah), Uma, Sekaran \& Bogie, Roger. (2017). "Metode Penelitian Untuk Bisnis". Jhon Wiley \& Sons, Inc. Jakarta: Salemba Empat.

https://ekonomi.kompas.com/read/2017/10/08/165552026/galeri-investasi-bursaefek-indonesia-incar-mahasiswa-jadi-investor. diakses tanggal 10 Oktober 2019.

https://idx.co.id/ diakses 10 Oktober 2019.

https://m.detik.com/finance/bursa-dan-valas/d-3218679/modal-rp-100000 -sudahbisa-investasi-saham-cocok-buat-karyawan. diakses tanggal 10 Oktober 2019.

https://pedomanbengkulu.com/2018/03/bei-buka-galeri-investasi-di-umb/.diakses tanggal 10 Oktober 2019. 